Original article

\title{
IMMUNOHISTOLOGICAL LOCALISATION OF GROWTH FACTORS IN STROMA AND INTERSTITIAL GLAND TISSUE OF GOAT (CAPRA HIRCUS) OVARY
}

\author{
S. SAINI \& R. A. BHAT \\ Department of Zoology, Kurukshetra University, Kurukshetra, India
}

\begin{abstract}
Summary
Saini, S. \& R. A. Bhat, 2021. Immunohistological localisation of growth factors in stroma and interstitial gland tissue of goat (Capra hircus) ovary. Bulg. J. Vet. Med., 24, No 4, 478-486.

The growth factors platelet derived growth factor (PDGF), transforming growth factor alpha (TGF- $\alpha$ ) and transforming growth factor beta (TGF- $\beta$ ) have been demonstrated to stimulate the in vitro proliferation of theca and granulosa cells in different animals. The present study was conducted to localise the growth factors PDGF, TGF- $\alpha$ and TGF- $\beta$ in different types of interstitial cells and stromal cells of normal cycling goat ovaries. Tissue fixed in formalin was processed through a graded series of alcohols and embedded in paraffin wax. The sections were immunohistochemically stained with antibodies against PDGF, TGF- $\alpha$ and TGF- $\beta$. The binding affinity of interstitial cells and stromal cells were observed and photographed. The staining pattern of PDGF, TGF- $\alpha$ and TGF- $\beta$ was mild to strong in stromal cells. The primary and secondary interstitial cells exhibited varied staining patterns for all studied growth factors. These findings in goat suggests that PDGF, TGF- $\alpha$, TGF- $\beta$ were potentially an important autocrine regulator of different cell functions and possibly a paracrine regulator of ovarian cell function at various development stages.
\end{abstract}

Key words: goat, ovary, PDGF, stroma, TGF- $\alpha$, TGF- $\beta$

\section{INTRODUCTION}

The ovary possesses five types of steroidogenic cells i. e. theca and granulosa cells in developing follicles, small and large antral cells in corpus luteum and interstitial cells in stroma (Sharma \& Batra, 2008). Besides the follicle and corpus luteum, the stroma forms the third most important compartment of the ovary (Guraya, 2000). Gonadotropins, ovarian steroids and various growth factors regu- late the proliferation and apoptosis of ovarian cells (Harman et al., 1975; Hurwitz \& Adashi, 1992; Tilly et al., 1992; Hsueh et al., 1994). It has been suggested that growth factors influence ovarian physiology in different stages of growth via endocrine, paracrine and autocrine mechanisms (Kaiser et al., 2001; Ulug et al., 2007). Various studies have been performed on the expression of growth fac- 
tors viz. platelet derived growth factor (PDGF), transforming growth factor alpha (TGF- $\alpha$ ) and transforming growth factor beta (TGF- $\beta$ ) by different cellular components of the ovary in several mammalian species: humans (Pinkas et al., 2008), rats (Kim \& Schomberg, 1989) and cows (Hernandez et al., 1990).

Functions of stroma especially that of interstitial gland cells in terms of hormone output, supplementary growth factors and peptides required for the transition of primordial to primary follicle, follicular recruitment, selection of follicles for growth and then induction of apoptotic changes are largely regulated by stromal components which are considered quiescent and nonfunctional in most of the studies (Guraya, 2000). The cytochemical and histochemical characteristics of various interstitial cell types suggest that they constitute the steroid producing cells of the ovarian stromal compartment (Guraya, 1991). Multiple studies have been performed in various mammalian species to demonstrate the roles of PDGF, TGF- $\alpha$ and TGF- $\beta$ protein in various aspects of ovarian development. However, to our knowledge, scanty literature is available that compares the expression and localisation of PDGF, TGF- $\alpha$ and TGF- $\beta$ in the intersitial and stromal cells of the caprine ovary. Thus, the aim of the study was to determine the expression and localisation of PDGF, TGF- $\alpha$ and TGF- $\beta$ in the stromal cells and interstitial gland tissue of caprine ovary.

\section{MATERIALS AND METHODS}

Cervical mucus samples were collected using plastic pipettes, to confirm the estrous stage. Immediately after collection, a smear was made using a drop of fresh mucus and then left to dry. The samples were examined with a low power microscope (Olympus, 10×) to observe a clear crystallised ferning pattern with long stems and clear venation fern visible during the mid-estrous stage. Goat ovaries $(n=10)$ of mid estrous phase were procured from the nearby abattoir at $4{ }^{\circ} \mathrm{C}$. The ovaries were placed in $10 \%$ neutral buffered formalin for $24 \mathrm{~h}$ and processed for paraffin embedding. Thereafter, immunohistochemistry was performed according to the method of Roy \& Kole (1995), where sections were cut at $5 \mu \mathrm{m}$ thickness and taken on Poly-L-lysine coated slides. The sections were dried overnight at $37{ }^{\circ} \mathrm{C}$, deparaffinised in xylene and rehydrated in a graded ethanol series. After washing in PBS, the epitopes were activated by microwaving the sections for 10 minutes to $100{ }^{\circ} \mathrm{C}$ at $600 \mathrm{~W}$ in citrate buffer ( $\mathrm{pH}$ 6.0). After microwave treatment, the sections were washed in PBS before being incubated for 5 minutes with ultra $\mathrm{V}$ to block nonspecific background staining. Thereafter, the sections were washed in PBS and incubated overnight at $4{ }^{\circ} \mathrm{C}$ with PDGF, TGF- $\alpha$ and TGF- $\beta$ antibodies produced in rabbit (1:50). After washing in PBS, sections were exposed for 45 minutes with biotinylated secondary antibody (goat anti rabbit IgG) diluted $(1: 200)$ in phosphatebuffered saline containing $1 \%$ normal goat serum. The selected sections were washed again in PBS and then incubated for 10 minutes with streptavidin alkaline phosphatase. The sections were rinsed in buffer, stained with fast red tablets dissolved in napthol phosphate substrate for 10-20 minutes. The sections were then counterstained with haematoxylin and mounted in glycerol. Slides were observed under the microscope and photographed. Immunohistochemical localisation of PDGF, TGF- $\alpha$ and TGF- $\beta$ was performed 
Immunohistological localisation of growth factors in stroma and interstitial gland tissue of goat ...

using specific monoclonal antibody (Calbiochem, Camarillo, CA, USA) and an immunostaining kit (Lab Vision Corporation, Warm Springs Blud. Fremont, CA, USA) was employed. In the evaluation of staining, $(+)$ has been used for weak staining, $(++)$ for mild staining and $(+++)$ has been used for strong staining patterns.

\section{RESULTS}

During the present study, observed binding patterns for different growth factors (PDGF, TGF- $\alpha$, and TGF- $\beta$ ) to different cellular components such as the stromal cells, primary interstitial gland cells and secondary interstitial gland cells of the goat ovary were of various affinity (Table 1). Interstitial gland cells, present in clus- ters or rows surrounding the developing and atretic follicles, corpus luteum and corpus albicans, constituted the main portion of stroma and were distinguished from the undifferentiated stroma, connective tissue by their glandular appearance, large size and prominent nucleus. The elliptical to polygonal shaped primary interstitial calls exhibited mild staining for PDGF when compared to the spherical shaped secondary interstitial cells exhibiting strong staining pattern. The uniformly stained cytoplasm was coarsely granulated with a prominent darkly stained nucleus (Fig. 1A, B). The stromal cells lying outside the different follicles were more or less spindle shaped, having coagulated cytoplasm. For PDGF, these fibroblast type stromal cells showed a strong stain-

Table 1. Pattern of reactivity of growth factors in different components of the normal cycling goat ovary

\begin{tabular}{lccc}
\hline Growth factors & Stroma & $\begin{array}{c}\text { Primary interstitial } \\
\text { gland cells }\end{array}$ & $\begin{array}{c}\text { Secondary interstitial } \\
\text { gland cells }\end{array}$ \\
\hline Platelet derived growth factor & ++ & ++ & +++ \\
Transforming growth factor $\alpha$ & ++ & ++ & + \\
Transforming growth factor $\beta$ & ++ & +++ & +++ \\
\hline
\end{tabular}
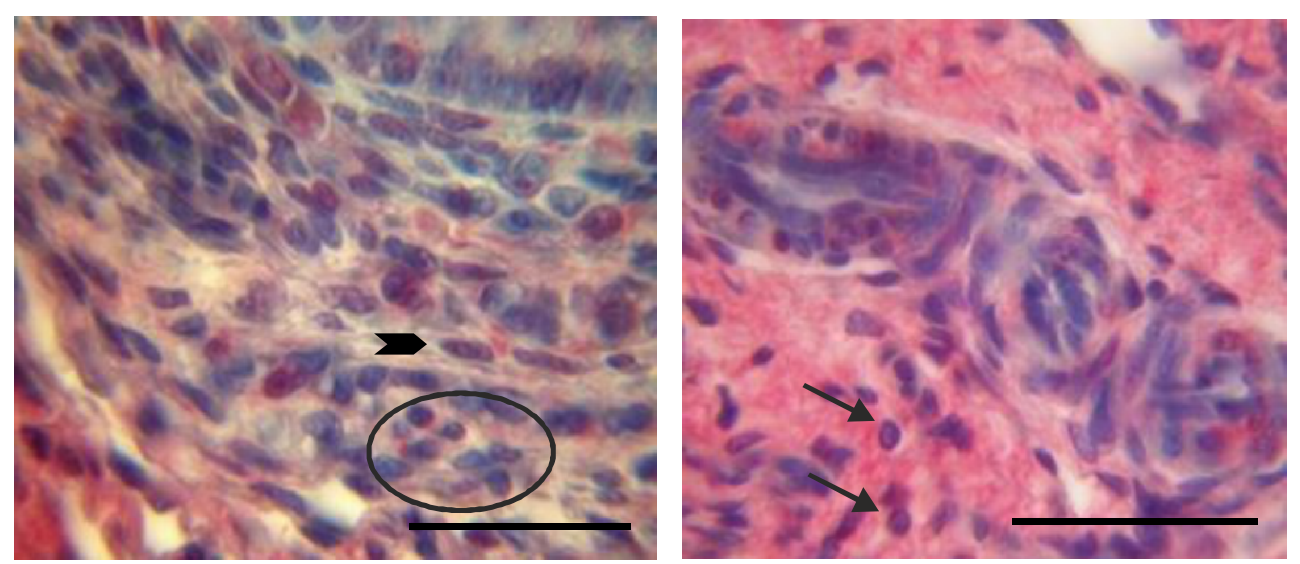

Fig. 1. Immunohistochemical localisation of PDGF in goat ovaries. Primary interstitial gland cells (circle) showing mild reactivity and secondary interstitial cells (arrow) exhibiting strong reactivity (asterisks). Stromal cells (arrowhead) with strong staining pattern are also visible. Bar $=10 \mu \mathrm{m}$. 

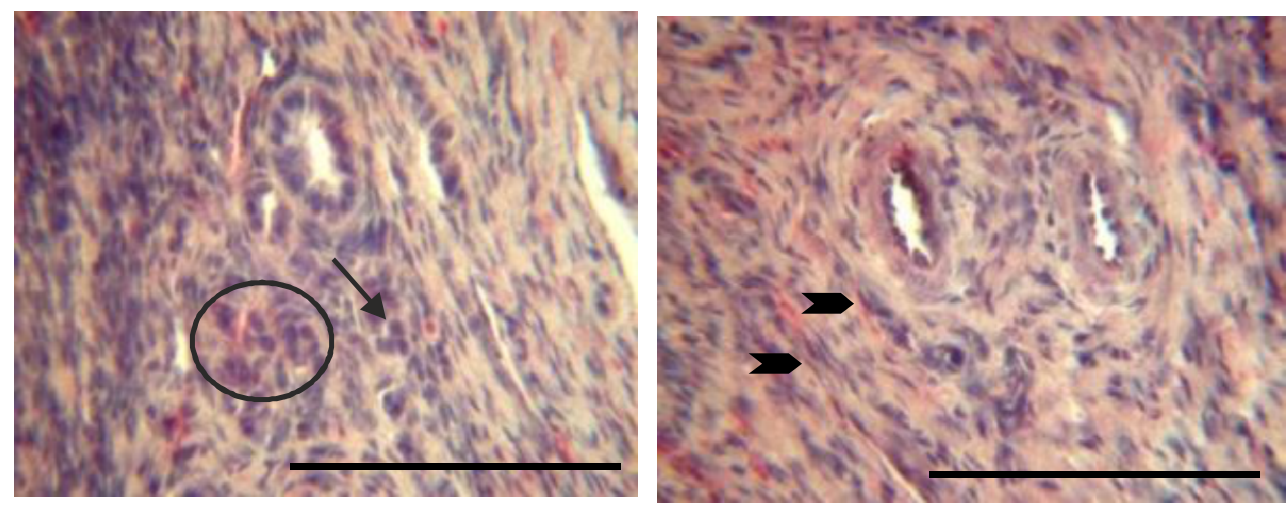

Fig. 2. Localisation of TGF- $\alpha$ in caprine ovary. Note the stromal cells (arrowheads) showing mild reactivity. The primary interstitial gland cells (circle) exhibited mild reactivity and the secondary interstitial cells (arrow): weak staining pattern. Bar $=40 \mu \mathrm{m}$.
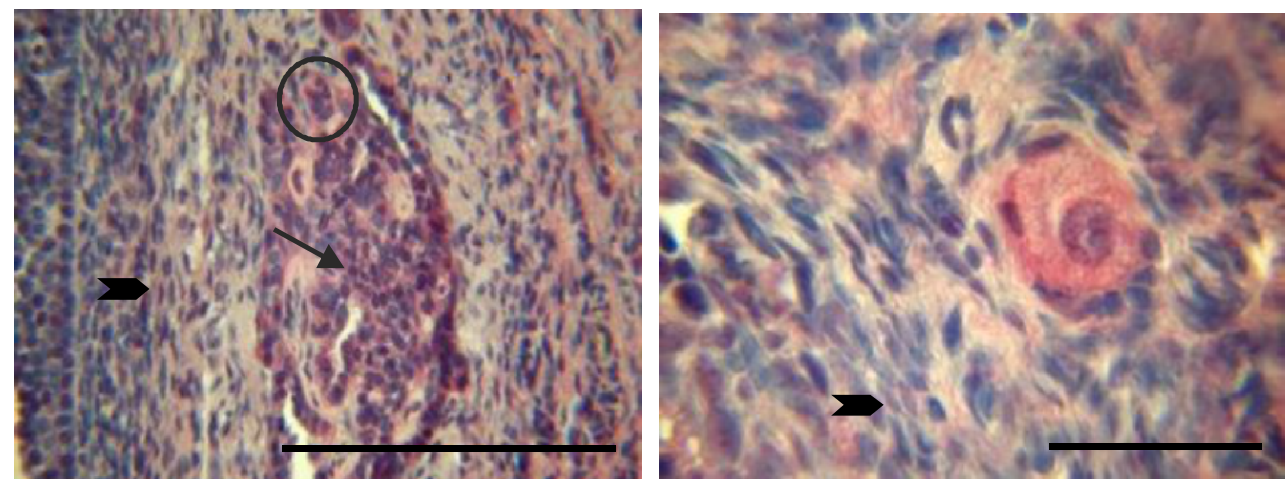

Fig. 3. Immunohistochemical localisation of TGF- $\beta$ in goat ovaries. Stromal cells (arrowhead) lying adjacently to the IGT are very mildly stained. The primary interstitial gland cells (circle) and secondary interstitial gland cells (arrow) both are strongly reactive to the TGF- $\beta$ protein. Bar $=10 \mu \mathrm{m}$ (left) and $40 \mu \mathrm{m}$ (right).

ing pattern which was uniform throughout the cytoplasm (Fig. 1A, B).

Immunostaining observed for TGF $\alpha$ in both primary and secondary interstitial cells was mild and weak respectively (Fig. $2 \mathrm{~A}, \mathrm{~B})$, whereas for growth factor TGF- $\beta$, both primary and secondary interstitial gland cells gave strong staining pattern (Fig. 3A, B). Immunostaining for TGF- $\beta$ was also localised in theca cell layers of primordial follicles which further proliferated to form several layers of cells around the follicle. In case of stromal cells, im- munohistochemical localisation for the protein TGF- $\alpha$ showed mild staining intensity (Fig. 2A, B), also during the localisation of TGF- $\beta$, reactivity observed was mild for these cells (Fig. 3A, B). The intercellular spaces between the cells were darkly stained for all studied growth factors.

\section{DISCUSSION}

In the present investigation, binding patterns for different growth factors (PDGF, 
Immunohistological localisation of growth factors in stroma and interstitial gland tissue of goat ...

TGF- $\alpha$ and TGF- $\beta$ ) to different cellular components of the goat ovary revealed varied affinity. Interstitial gland cells which were usually found to be present in clusters or rows surrounding the developing and atretic follicles, corpus luteum and corpus albicans, constituted the main portion of stroma and were distinguished from the undifferentiated stroma, connective tissue by their glandular appearance, large size and prominent nucleus. For PDGF, primary interstitial cells exhibited mild staining compared to the spherical shaped secondary interstitial cells exhibiting strong staining pattern. Our results are in accordance with the study carried out by Nilsson et al., (2006) who have reported that the oocyte produces PDGF, that subsequently acts upon surrounding granulosa and interstitial cells to promote primordial follicle transition, suggesting the role of interstitium in follicular development and growth in the caprine ovary.

Immunostaining observed during the present study for TGF- $\alpha$ in both primary and secondary interstitial cells was mild and weak respectively which is further validated by the previous studies establishing the localisation of TGF- $\alpha$ in the theca interstitial cells of the rat ovary (Kudlow et al., 1987). Therefore, present findings support the role of interstitium in follicular development and growth in the caprine ovary. Both primary and secondary interstitial gland cells were found to be strongly stained for the growth factor TGF- $\beta$, in accordance with the previous studies on adult rat ovary exhibiting intense immunostaining for TGF- $\beta$ (Teerds $\&$ Dorrington, 1995). In their study on quail ovary Van Nassauw et al. (1996) put forward that TGF $\beta 2$ is the predominant isoform in interstitial cells. TGF $\beta 1$ is found in pre-pubertal as well as in adult ovarian interstitium in the hamster (Roy \&
Huges, 1994). Human ovaries have also been reported to express TGF $\beta$ RII in the interstitial compartment (Roy \& Kole, 1998). Taken together, these data indicate that TGF- $\beta$ may play a positive role in regulating some functions of interstitial gland cells too. Foghi et al. (1997) showed increased apoptosis of thecal and interstitial cells in response to TGF $\beta$ treatment.

The stromal cells lying outside the different follicles showed a strong staining pattern for PDGF which was uniform throughout the cytoplasm. Previously it has been demonstrated that plateletderived growth factor (PDGF) stimulated in vitro proliferation of theca cells of antral follicles in both rat (Duleba et al., 1999) and pig (May et al., 1992; Taylor, 2000; Shores \& Hunter, 2000) while inhibiting thecal LH-induced steroid hormone synthesis. In human ovaries, four PDGF isoforms (PDGFa, PDGFb, PDGFc, and PDGFd) transcripts have been identified (Fredriksson, 2004), but similar information in caprine ovary is not available. The theca cell layer of adult porcine ovaries has been shown immunopositive for PDGFRB (Taylor, 2000) and porcine antral follicles PDGFRA has been localised in theca cells and weakly to basal granulosa cells (Chegini \& Williams, 1992). Expression of the PDGFRB protein was localised to stromal cells surrounding clusters of oocytes in the newborn rat ovary. Likewise, the present study indicates that the stromal cells were strongly reactive to the protein PDGF. Similarly, stromal cells in the human foetal ovary also expressed PDGF (Pinkas et al., 2008). These actions of PDGF may provide mechanisms for selective development of ovarian stroma which contributes to ovarian structural integrity and possess steroidogenic activity. Herrera et al. 
(2005) have reported that PDGFR-b in ovarian stromal cells of newborn mice, around newly formed primary follicles, and in a few cells that intercalate oocyte clusters, thus concluding that PDGFRb plays a direct role in the differentiation of ovarian stroma. Similarly, from the results obtained in the current study showing strong staining pattern by stromal cells surrounding the follicles with PDGF it can be suggested that the growth factor PDGF has a role in differentiation and the growth of ovarian stroma.

Immunohistochemical localisation of the protein TGF- $\alpha$ showed mild staining in stromal cells. The major role of TGF- $\alpha$ is its influence on steroidogenesis. In human ovaries, Chegini \& Williams (1992) established the immunohistochemical localisation of TGF- $\alpha$ in stromal cells with moderate staining supporting the present study on stromal cells for the same protein. However, contrary to the present work, Jianping (2000), observed weak staining intensity in stromal cells of human ovarian tissue. The previous studies revealed that during early stages of maturation TGF- $\alpha$ was detectable in the oocyte of human ovaries, when granulosa and theca cells showed no growth factor expression, whereas with further follicular development, staining of the oocyte disappeared, and the granulosa and theca cells began to show TGF- $\alpha$ staining. Only theca interna cells showed strong immunostaining for TGF- $\alpha$ during late follicular development. Also, during the course of follicular regression, theca cells remained strongly positive for TGF- $\alpha$ (Reeka et al., 1998). As theca cells are only associated with growing follicles, it is assumed that signals to the stroma for the recruitment of cells that form the theca are produced by follicle itself. Also, the interstitial gland cells of the mammalian ovary are thought to originate from the theca interna and surrounding stromal elements of degenerating follicles and are simultaneously vascularised and hypertrophied (Guraya, 1991). Immunostaining observed during the present study for TGF $\alpha$ in both primary and secondary interstitial cells was mild and weak respectively which is further validated by the previous studies establishing the localisation of TGF $\alpha$ in the theca interstitial cells of the rat ovary (Kudlow et al., 1987). These findings support the role of both stroma and interstitium in follicular development and growth in the caprine ovary. The present findings confirm the presence of the protein TGF $\alpha$ in stromal cells and interstitium of goat ovary providing an evidence suggesting that an activated follicle produces factors that induce thecal cell differentiation from stroma, although the exact identity and combination of the proteins is still to be known.

In this study, reactivity was mild for stromal cells during the localisation of TGF- $\beta$ in goat ovary. TGF- $\beta$ are polypeptide growth factors that affect the metabolic activity of each cell types in the ovary i.e. thecal/interstitial cells, granulosa cells and oocytes (Feng et al., 1986; Kim \& Schomberg, 1989). Observations made during the current study revealed mild staining for the TGF- $\beta$ in stromal cells, which are similar to the previous reports by Nilsson et al. (2003) in bovine ovary, indicating potential role of TGF- $\beta$ in regulating certain functions in ovarian stroma. In one of the studies Chegini \& Flanders (1992) put forward that TGF $\beta 1$ is expressed in the stroma. The observations that TGF $\beta$ is immunohistochemically localised in stromal cells as well as in different ovarian tissues (Dodson \& Schomberg, 1987; Dorrington et al., 1988; Kim \& Schomberg, 1989; Hernan- 
Immunohistological localisation of growth factors in stroma and interstitial gland tissue of goat ...

dez et al., 1990) suggests that specific TGF $\beta$ signalling events are important for the regulation of these tissues. Immunostaining for TGF- $\beta$ was noted strong in interstitium of goat ovary during the present study, which is in accordance with the previous studies on adult rat ovary exhibiting intense immunoreactivity for TGF- $\beta$ (Teerds \& Dorrington, 1995). Having studied quail ovary, Van Nassauw et al. (1996) put forward that TGF $\beta 2$ was the predominant isoform in stromal and interstitial cells. TGF $\beta 1$ was found in prepubertal as well as in adult ovarian interstitium in the hamster (Roy \& Hughes, 1994). Human ovaries have also been reported to express TGF $\beta$ RII in the stromal/interstitial compartment (Roy \& Kole, 1998). Taken together, these data indicate that TGF $\beta$, may play a positive role in regulating some functions of interstitial gland cells too. Foghi et al. (1997) showed increased apoptosis of thecal and interstitial cells in response to TGF $\beta$ treatment. The expression of TGF $\beta$ receptors was observed in ovarian stroma (Roy \& Kole, 1995; Nilsson et al., 2003).

\section{CONCLUSIONS}

In conclusion, all these data on the localisation of different growth factors viz. PDGF, TGF $\alpha$, TGF $\beta$ suggest the existence of their multiple autocrine or paracrine actions on the stromal and interstitial cells. A better understanding of the regulation of these growth factor's production and secretion in stroma and interstitium cells will help to determine the events that lead to normal controlled proliferation of these cells.

\section{REFERENCES}

Chegini, N. \& K. C. Flanders, 1992. Presence of transforming growth factor-beta and their selective cellular localization in human ovarian tissue of various reproductive stages. Endocrinology, 130, 1707-1715.

Chegini, N. \& R. S. Williams, 1992. Immunocytochemical localization of transforming growth factors (TGFs) TGF-alpha and TGF-beta in human ovarian tissues. Journal of Clinical Endocrinology and Metabolism, 74, 973-980.

Dodson, W. C. \& D. W. Schomberg, 1987. The effect of transforming growth factorbeta on follicle-stimulating hormone-induced differentiation of cultured rat granulosa cells. Endocrinology, 120, 512-516.

Dorrington, J., A. V. Chuma \& J. J. Bendell, 1988. Transforming growth factor beta and follicle-stimulating hormone promote rat granulosa cell proliferation. Endocrinology, 123, 353-359.

Duleba, A. J., R. Z. Spaczynski, A. Arici, R. Carbone \& H. R. Behrman, 1999. Proliferation and differentiation of rat thecainterstitial cells: Comparison of effects induced by platelet-derived growth factor and insulin-like growth factor-I. Biology of Reproduction, 60, 546-550.

Feng, P., K. J. Catt \& M. Knecht, 1986. Transforming growth factor 13 regulates the inhibitory actions of epidermal growth factor during granulosa cell differentiation. The Journal of Biological Chemistry, 261, 14167-14170.

Foghi, A., K. J. Teerds, H. van der Donk \& J. Dorrington, 1997. Induction of apoptosis in rat thecal/interstitial cells by transforming growth factor alpha plus transforming growth factor beta in vitro. Journal of Endocrinology, 153, 169-178.

Fredriksson, L., H. Li \& U. Eriksson, 2004. The Pdgf family: Four gene products form five dimeric isoforms. Cytokine and Growth Factor Reviews, 15, 197-204.

Guraya, S. S., 1991. Interstitial cells. In: Ultrastructure of the Ovary, eds G. Famil- 
iani, P. M. Motta \& S. Makabe, Kluwer Academic Publishers, Norwell, U.S.A, pp.199-224.

Guraya, S. S., 2000. Comparative Cellular and Molecular Biology of Ovary in Mammals: Fundamental and Applied Aspects. Oxford and IBH Publishing Co. Pvt. Ltd., India.

Harman, S. M., J. P. Louvet \& G. T. Ross, 1975. Interaction of estrogen and gonadotropins on follicular atresia. Endocrinology, 96, 1145-1152.

Hernandez, E. R., A. Hurwitz, D. W. Payne, A. M. Dharmarajan, A. F. Purchio \& E. Y. Adashi, 1990. Transforming growth factor$\beta 1$ inhibits ovarian androgen production: gene expression, cellular localization, mechanisms(s) and site(s) of action. Endocrinology, 127, 2804-2811.

Herrera L, C. Ottolenghi, J. E. Garcia-Ortiz, M. Pellegrini, F. Manini, M. S. Ko, R. A. Nagaraja Forabosco \& D. Schlessinger, 2005. Mouse ovary developmental RNA and protein markers from gene expression profiling. Developmental Biology, 279 , 271-290.

Hsueh, A. J., H. Billig \& A. Tsafriri, 1994. Ovarian follicle atresia: A hormonally controlled apoptotic process. Endocrinology Reviews, 15, 707-724.

Hurwitz, A. \& E. Y. Adashi, 1992. Ovarian follicular atresia as an apoptotic process: a paradigm for programmed cell death in endocrine tissues. Molecular and Cellular Endocrinology, 84, C19-C23.

Jianping, Q., M. D. Michelle Nisolle \& M. D. Jacques Donnez, 2000. Expression of transforming growth factor-alpha, epidermal growth factor, and epidermal growth factor receptor in follicles of human ovarian tissue before and after cryopreservation. Fertility and Sterility, 74, 113-121.

Kaiser, G. G., F. Sinowaz \& G.A. Palma, 2001. Effects of growth hormone on female reproductive organs. Anatomia Histologia Embryologia, 30, 285-271.

Kim, I. C. \& D. W. Schomberg, 1989. The production of transforming growth factor-
13 activity by rat granulosa cell cultures. Endocrinology, 124, 1345-1351.

Kudlow, J. E., M. S. Kobrin, A. F. Purchio, D.R. Twardzik, E. R. Hernandez, S. L. Asa \& E. Y. Adashi, 1987. Ovarian transforming growth factor- $\alpha$ gene expression: Immunohistochemical localization to the theca interstitial cells. Endocrinology, 121, 1577-1579.

May, J. V., A. J. Bridge, E. D. Gotcher \& B. K. Gangrade, 1992. The regulation of porcine theca cell proliferation in vitro: Synergistic actions of epidermal growth factor and platelet-derived growth factor. Endocrinology, 131, 689-697.

Nilsson, E. E., C. Detzel \& M. K. Skinner, 2006. Platelet-derived growth factor modulates the primordial to primary follicle transition. Reproduction and Fertility, 1741-7899.

Nilsson, E. E., V. Doraiswamy \& M. K. Skinner, 2003. Transforming growth factorbeta isoform expression during bovine ovarian antral follicle development. Molecular Reproductive Development, 66 , 237-246.

Pinkas, H., B. Fisch, G. Rozansky, C. Felz, G. Kessler-Icekson, H. Krissi, S. Nitke, A. Ao \& R. Abir, 2008. Platelet-derived growth factors (PDGF-a and -b) and their receptors in human fetal and adult ovaries. Molecular Human Reproduction, 14, 199-206.

Reeka, N., F. D. Berg \& C. Brucker, 1998. Presence of transforming growth factor alpha and epidermal growth factor in human ovarian tissue and follicular fluid. Human Reproduction, 13, 2199-2205.

Roy, S. K. \& J. Hughes, 1994. Ontogeny of granulosa cells in the ovary: Lineagespecific expression of transforming growth factor beta 2 and transforming growth factor beta 1. Biology of Reproduction, 51, 821-830.

Roy, S. K. \& A. R. Kole, 1995. Transforming growth factor-b receptor Type II (T b RII) expression in the hamster ovary: Cellular site(s), biochemical properties and hormo- 
Immunohistological localisation of growth factors in stroma and interstitial gland tissue of goat ...

nal regulation. Endocrinology, 136, 4610 4620.

Roy, S. K. \& A. R. Kole, 1998. Ovarian transforming growth factor-beta (TGF-beta) receptors: In-vitro effects of follicle stimulating hormone, epidermal growth factor and TGF-beta on receptor expression in human preantral follicles. Molecular Human Reproduction, 4, 207-214.

Sharma, R. K. \& S. Batra, 2008. Changes in the steroidogenic cells of the ovaries in small ruminants - a review. Indian Journal of Animal Science, 78, 554-596.

Sharma, R. K. \& J. K. Bhardwaj, 2009. In situ evaluation of granulosa cells during apoptosis in caprine ovary. International Journal of Integrative Biology, 5, 60.

Shores, E.M. \& M.G. Hunter, 2000. The influence of blood cells and PDGF on porcine theca cell function in vitro. Animal Reproduction Science, 64, 247- 258.

Taylor, C. C., 2000. Platelet-derived growth factor activates porcine thecal cell phosphatidylinositol-3-kinase-Akt/PKB and ras-extracellular signal-regulated kinase$1 / 2$ kinase signaling pathways via the platelet-derived growth factor-beta receptor. Endocrinology, 141, 1545-1553.

Teerds, K. J. \& J. H. Dorrington, 1995. Immunohistochemical localization of transforming factor-3 and -2 during follicular development in the adult rat ovary. Molecular and Cellular Endocrinology, 52, 500-508.
Tilly, J. L., H. Billig, K. I. Kowalski \& A. J. Hsueh, 1992. Epidermal growth factor and basic fibroblast growth factor suppress the spontaneous onset of apoptosis in cultured rat ovarian granulosa cells and follicles by a tyrosine kinase-dependent mechanism. Molecular Endocrinology, 6, 1942-1950.

Ulug, U., E. Turan, S. B. Tosun, H. F. Erden $\&$ M. Bahceci, 2007. Comparison of preovulatory follicular concenteration of epidermal growth factor, insulin-like growth factor-I, and inhibin, $\mathrm{a}$ and $\mathrm{b}$ in woman undergoing assisted conception treatment with gonadotropin-releasing hormone (GnRH) agonists and GnRH antagonists. Fertility and Sterility, 87, 995-998.

Van Nassauw, L., A. Schrevens \& F. Harrisson, 1996. Immunohistochemical localization of transforming growth factor beta 1 and beta 2 during folliculogenesis in the quail ovary. Histochemical Journal, 28, 859-865.

Paper received 30.11.2019; accepted for publication 20.01.2020

\section{Correspondence:}

Bhat Rayees Ahmad

Department of Zoology,

Kurukshetra University,

Kurukshetra, India

e-mail: bhatrayees8@gmail.com 